DOI https://doi.org/10.32405/2218-7650-2020-13(42)-200-212

УДК 373.1.02; 373.1.02:372.8

Aygun Rustamova,

Employee of the Nakhchivan State University

PhD student of Nakhchivan State University.

Nakhchivan, Azerbaijan.

ORCID iD: https://orcid.org/0000-0003-2682-9485

res0980@mail.ru

\title{
INITIATION OF TRAINING ACTIVITIES FOR JUNIOR SCHOOLCHILDREN. CRISIS OF AGES 6-7
}

\begin{abstract}
The article discusses the beginning of training activities for junior schoolchildren and the crisis of ages 6-7. Starting learning activities for children aged 6-7 is one of the most important problems of primary education in terms of adaptation to school environment. During this period, many changes occur in connection with the psychophysiological development of the child. Thus, the child combines the features of the preschool age with the features of the school age. This age period is still relevant today, despite the fact that it is sufficiently studied in the different fields, particularly in the psychological and pedagogical literature. The article also touches on the psychological characteristics of junior schoolchildren. It should be noted that children entering the first grade enter a new state of social development, as play is replaced by learning activities, in which children not only acquire new rights and responsibilities, but also the responsibilities they acquire must meet the requirements of school. Based on the results of the study, we can say that in order for children aged 6-7 to easily adapt to learning activities, it is necessary to prepare them for some kind of learning by creating interest in school. On the other hand, success in adapting junior schoolchildren to learning will be achieved if their cognitive and emotional characteristics are taken into account. The results of observations, surveys and experiments conducted at the secondary school named after H.Aliyev in Nakhchivan in 2017-2019, as well as the materials indicated in the bibliography were used in the preparation of the article.
\end{abstract}

Keywords: junior schoolchildren; training activity; adaptation; crisis of ages 6-7; subject; mental processes; physical development; emotional; preschool; behavior. 


\section{INTRODUCTION / ВСТУП / ВВЕДЕНИЕ}

Formulation of the problem. The preschool child's lifestyle changes radically in connection with the transition to school. During this period, his/her life includes systematic, organized, responsible, compulsory learning activities. In contrast to the preschool age, the schoolchild is faced with the task of consistent acquisition of generalized and systematized knowledge on the basis of sciences that provide a different structure of cognitive activity. Starting school is a serious test for most junior schoolchildren. They must get used to the new team, new requirements, daily tasks, adapt to new conditions. The purpose of adaptation is not only to adapt the junior schoolchildren to successful activities in the educational environment, but also to ensure his/her personal, psychological and social development. In this case, the child's position changes and the daily and habitual life is reconstructed in connection with the new leading activity. At the end of the preschool period, the child begins to change. This change is reflected not only in his/her appearance but also in his/her behavior. Thus, the child begins to cry for no reason, to be sad, to be whimsical, in short, to behave differently than in preschool. These features are considered the main signs of the transition from preschool to school age and are called the crisis of ages six-seven in the psychological literature. At this time, serious changes occur in the child's mental processes. Based on the principle of «I grew up», a junior schoolchild tries to get his/her ideas and thoughts accepted by adults.

Analysis of the latest relevant research and publications. The analysis of the relevant scientific literature shows that the principles of the initiation of training activities for junior schoolchildren and the issue of crisis of ages 6-7 have been studied by E. Simernichkaya, V. Kozlov, D. Farber, S. Springer, Q. Deych and others.

\section{AIM AND TASKS / МЕТА ТА ЗАВДАННЯ / ЦЕЛИ И ЗАДАЧИ}

The aim of the research is to analyze learning activities of children aged 6-7 of primary education in terms of adaptation to school environment.

In accordance with this goal, the article sets the following tasks: responsibly;

- to consider types of ability to perform schoolchildren`s activities

- to establish the factors of overcoming the crisis of the age of 6-7;

- identify barriers to socio-cultural life in the school environment. 


\section{THE THEORETICAL BACKGROUNDS / TEOPETИЧНI ОСНОВИ ДОСЛІДЖЕННЯ / ТЕОРЕТИЧЕСКИЕ ОСНОВЫ ИССЛЕДОВАНИЯ}

Junior school age covers the period between 6-7 and 10-11 years, and the most important event in a schoolchild's life is determined by his or her enrollment in school. This age is extremely important for the psychological and social development of the child. Purposeful learning activities take the first place in the development of the schoolchild, as during this period he/she acquires knowledge under the influence of learning activities. The ability to control the behavior of a junior schoolchild, who has already become a subject of learning activities, is developing. The main general-theoretical methods in the study are: historiographical, comparative, modeling, abstraction, concretization, which meets the need for a holistic, interconnected analysis to substantiate the principles of integrating the concepts of social activity of the schoolchildren aged 6-7 in the school system.

\section{RESEARCH METHODS / МЕTОДИ ДОСЛІДЖЕННЯ / МЕТОДЫ ИССЛЕДОВАНИЯ}

This analysis was conducted with the study of the sources related to the subject, the analysis of the results obtained, the analysis and synthesis of the arguments, and also the comparative analysis method. Books and articles such as L. Amrahli, M. Aliyeva «Training activity and mental development»; A. Rogova «Development of the emotional sphere of young schoolchildren with intellectual disabilities in reading lessons»; A. Weitz «Psychological characteristics of children of junior school age with neurosis-like disorders»; E. Sergienko, T. Marcinkovskaya, E. Izotova, E. Lebedeva, A. Ulanova, E. Dubovskaya «Socioemotional development of children», methodical aids, dissertations, at the same time, the results of theoretical methods such as analysis, synthesis, generalization, comparison, empirical methods such as questionnaires, surveys, tests conducted on young schoolchildren at the Heydar Aliyev School in Nakhchivan were used.

\section{RESEARCH RESULTS / РЕЗУЛЬTАТИ ДОСЛІДЖЕННЯ / РЕЗУЛЬТАТЫ ИССЛЕДОВАНИЯ}

Starting a learning activity is a turning point in a child's life. In the psychological literature, this is referred to as the crisis of ages $6-7$, the end of the preschool period, or the beginning of the junior school age. During this period, many changes occur in connection with the psychophysiological development of the child. This change is due to his/her growth and the beginning of training 
activities. It is called the transition period for a child aged 6-7. Thus, the child combines the features of the preschool age with the features of the school age. These features manifest themselves in the form of complex compounds that sometimes contradict each other in his/her behavior and consciousness. At this time, a sensitive period begins for the child, laying the foundation for the future development of his/her personality.

The initial stage of training is the period of active adaptation of the child to new conditions, although the formation of the schoolchild's social orientation does not occur immediately. In order for a child to acquire knowledge, realize that he/she has to learn, and change his/her behavior, he/he must move to a new level of relationships in the family and at school. This period is problematic for children aged 6-7, because the child's parents begin to set more stringent requirements for him/her than in preschool. An important step in the adaptation of junior schoolchildren is the mandatory implementation of rules governing the behavior of schoolchildren. The rules aim to ensure that the class as a whole and each schoolchild can be productive.

«The role of training in mental development is explained from different perspectives. Training is, above all, a form of children's activity, the main activity of junior schoolchildren. The conditions and conditions under which this activity is organized are connected with the dynamic effects it can have on mental development» [1, p. 27]. The main features of systematic training are as follows: first, when entering the school, the child begins to carry out socially assessed activities - learning activities; second, school training requires a number of obligations for all of the same rules governing all schoolchild behavior while in school which is a problem for most of them. Every child faces at least one of the following problems:

- changes in daily routine, difficulties in regulating behavior;

- communication difficulties (most often observed in children with little experience of communication with peers);

- inability to determine their place and position in the classroom;

- difficulties in interaction with the teacher;

- unformed elements of learning activities;

- unformed learning motivation;

- inability to voluntarily regulate behavior and mental processes;

- inability to adapt to the pace of school life;

The school environment is very different from the preschool staff. Its main difference is that it requires a junior schoolchild to make an intellectual effort. If a preschooler can express his/her emotions and desires directly, a junior 
schoolchild can't. «The need to follow socially accepted rules sets the boundaries between 'can' and 'can't' in a schoolchild» [5, p. 50]. It should be taken into consideration that the child does not want to be junior, he/she is already «adult» because goes to school. By the end of the first grade, the schoolchild realizes the tasks facing the whole class and tries to complete the learning tasks independently. His/her status is changing - he/she is already schoolchild, which stimulates the formation of the child's system of interpersonal relationships. Participating in school life creates a sense of collectivism in children and requires help to build relationships. As a result, junior schoolchild gains useful behavioral experience, such as the division and fulfillment of responsibilities in the classroom, and mutual responsibility. Based on the experience gained, primary school children develop a sense of duty and responsibility, the ability to manage their emotions and regulate their personal interests in favor of collective goals. Behavioral standards that emerge in the classroom have a significant impact on the formation of a sense of friendship among junior schoolchildren. Friendships between children in different classes are different. This type of relationship is not stable for 6-7 year old schoolchildren due to weak friendship motives. Thus, at the beginning of training, children behave very far from each other. Often children of this age change their friends for random and subjective reasons. The friendship of primary school schoolchildren is based on common interests, such as play activities, spending free time, walking and so on. The teacher plays a central role in the relationship between them, and the organization of joint activities with the teacher's leadership and the definition of its common goals leads to friendship and camaraderie in interpersonal relationships, which allows the child to determine his/her place among peers. Gradually, children between the ages of seven and nine develop a friendly relationship based on relatively limited interests. As a child enters school, his/her behavior changes completely. In the past, a child's behavior was regulated by his/her feelings, but now the moral norms of his/her behavior are purposefully brought up by the teacher, and these norms become a necessary condition in the classroom. The teacher must teach the schoolchild the rules, norms and requirements of the general class discipline. Under the guidance of the teacher, the schoolchild begins to behave in accordance with the rules of discipline in the classroom, mastering the new responsibilities of learning activities. It is these norms of behavior that affect the content of a child's activities and have a positive effect on his or her adaptation to learning.

At the ages 6-7 years, intensive biological growth also occurs, which stimulates the formation of the child's body. Intensive development of the muscular system occurs. The large muscles of the body, arms and legs of a six- 
year-old child are sufficiently developed, but because the small muscles, which are important for maintaining the correct position of the spine while sitting, are relatively weak, static tension causes muscle fatigue, the child begins to change posture and the spine is easily deformed. «With the development of small hand muscles, the ability to perform subtle movements develops, thanks to which the child acquires the ability to write quickly» [2, p.11]. Noting that the musculoskeletal system is underdeveloped in six-year-old children, the researchers emphasize the importance of increasing physical activity in children of this age. At the age of six, a child begins deep structural changes in the cerebral cortex. "The process of lateralization of the functions of the cerebral hemispheres, which began at the age of five, is coming to an end. (E. Simernichkaya, 1978; V. Kozlov, D. Farber, 1983; S. Springer, Q. Deych, 1983)» [4, p. 11].

A distinctive feature of the school position for the child is the transformation of education into a mandatory, socially important activity. The schoolchild is responsible to the teacher, school, family. The schoolchild's life is now subject to a system of strict rules that are the same for all schoolchildren. The acquisition of knowledge becomes the main goal of the training activity. The schoolchild must take the learning activity seriously, understand its social significance, and obey the requirements and laws of school life.

The beginning of school training causes a radical change in the social development of the schoolchild. He/she understands that he/she has to read, and for this should change his/her behavior. At the same time, he/she realizes that he/she is different from other classmates because of his/her individual characteristics.

Within the framework of learning activities, the main psychological features that characterize the most important achievements in the development of the schoolchild and ensure his/her development at a later age are formed. «The perception of children between the ages of 6-7 is significantly improving. Thus, a junior schoolchild is able to distinguish objects according to shape, size and color, determine their position, draw simple objects and paint them in a certain color. However, children still do not know exactly how to distinguish very similar objects and have difficulty in generalizing objects. These skills are formed at the beginning of adolescence» [3, p. 14]. The involuntary attention of junior schoolchildren is predominant, as the schoolchild focuses on an object that is of interest and emotional impact to him or her without any effort. Voluntary attention is relatively poorly developed, which often leads to difficulties in mastering the training material and a lack of discipline. For children aged $6-7$, it is difficult to focus on something interesting or 
uninteresting, and this usually requires physical effort from them. At this age, abstract-logical thinking is formed rapidly - the child gradually learns to think, draw conclusions, make decisions, but such thinking reaches its peak during adolescence. Successful adaptation to learning activities creates conditions for the development of mental development, theoretical thinking and consciousness of the junior schoolchild. As a result, the age of six or seven is considered a turning point in the individual and mental development of the child. Systematic mastering of learning materials enriches children with new knowledge and gives them a new content in their mental activity, and this new content changes the nature of mental processes and brain activity. Changes in the mental processes of junior schoolchildren occur mainly in the form of what the child remembers and does not think, but how thinks and remembers.

A schoolchild aged 6-7 begins to take a new position in the existing system of relationships. This is primarily due to the fact that he/she enters the school and takes on certain social responsibilities that require a conscious and responsible attitude. "The schoolchild is confronted with the motive "I want" and the motive "need" by starting the learning activity» [2, p. 10-11]. Thus, he/she enters the conscious stage of personality formation. The emotions of children aged 6-7 change as begins school. If a preschooler enjoys the process of engaging in play activities with their parents and peers using toys, for a 6-7 year old, the learning process, school and everything related to the teacher are more important to him/her. On the other hand, children who are just beginning learning activities often have difficulty regulating their emotional manifestations, which are usually apparently reflected in their facial expressions and postures. The early school age is emotionally "contagious». Individual schoolchildren may laugh at other schoolchildren in the class. At the same time, a 6-year-old schoolchild may start to cry in front of classmates' tears, not because he/she is faced with a task she cannot solve, but because sees peers' tears. The learning process affects the emotional development of the child: when he/she succeeds in lessons, positive emotions are formed, the schoolchild's desire to learn is further developed.

\section{CONCLUSIONS AND PROSPECTS FOR FURTHER RESEARCH / ВИСНОВКИ ТА ПЕРСПЕКТИВИ ПОДАЛЬШИХ ДОСЛІДЖЕНЬ / ВЫВОДЫ И ПЕРСПЕКТИВЫ ДАЛЬНЕЙШИХ ИССЛЕДОВАНИЙ}

In order for children aged 6-7 to easily adapt to learning activities and overcome the crisis period, they must feel like a subject of learning activities, in other words, they must be ready for learning activities. From a physiological and psychological point of view, learning activities are determined, first of all, by the 
level of intellectual development of the child. The child's readiness for learning activities is reflected in the formation of his/her inner position, fulfillment of requirements and rules. Preparation for training activities means the formation of attitudes to school, learning, entering a new environment, the world of adults. A child's readiness for school is determined by fulfillment a number of requirements. These include the general physical development of the child; ability to have sufficient knowledge; ability to communicate and interact; behavioral culture; includes a desire to learn.

As a result of mastering these requirements, the child realizes the need to sit quietly during the lesson, listen to and understand the teacher, perform learning tasks, in short, follow certain rules. Our research conducted in 20172019 at the secondary school named after H. Aliyev in Nakhchivan showed that the majority of children aged 6-7 who previously went to preschool are ready to perform learning tasks and interact with the teacher, showing a positive attitude to learning activities, on the other hand, an unfavorable emotional background has a negative impact on the learning motivation of junior schoolchildren. Thus, we can say that the higher the anxiety of a junior schoolchild during the adaptation to learning activities, the more painful the crisis of ages 6-7 can be.

Summarizing the above, we can note that as a result of overcoming the crisis of the age of 6-7, the following reflexive skills are formed in children:

- Adequate self-acceptance;

- Ability to work within a team;

- To feel like a member of the team;

- Ability to perform their activities responsibly;

- Set a goal for action;

- Analyze the results of the activity;

- Relate the results to the purpose of the activity;

- To determine the presence of errors in their behavior;

- Make efforts for socially important activities;

- Ability to manage behavior;

- Ability to make simple generalizations;

- Practical development of speech.

Prospects for further research. The study found that 6-7 years of age is one of the most psychologically and physiologically complex and crucial periods in a child's life. This period, the leading activity of which is training, is also called the crisis of 6-7 years in the psychological and pedagogical literature. It is known that when a child enters school, he/she does not immediately become a schoolchild, on the contrary, he/she experiences more fatigue than in the pre- 
school period due to his/her increased psychological burden, which leads to a decrease in his/her learning activities and interest in learning. This is because learning activities require a junior schoolchild to be able to focus on mental processes such as attention, perception, memory, etc., as well as the development of individual characteristics, proper interaction with classmates and teachers, and successful adaptation. All this leads to a crisis of 6-7 years.

As mentioned in the article, the transition period for a child is 6-7 years. Thus, the child combines the features of the preschool age with the features of the school age. These features manifest themselves in his/her behavior and consciousness in the form of complex compounds that sometimes contradict each other. The main factors that cause the crisis of 6-7 years are the difficulties that children face in adapting to learning activities - changes in daily routine, learning to play, physical and intellectual fatigue, the need to form their own status in the classroom, proper communication with peers and teachers. is considered a necessity. In short, the structure of the rights and responsibilities of the junior schoolchild in both the school and the family is changing. These changes take three forms (violation of family rules; desire to prove that they have grown up-independence; imitation of adult behavior).

It should be noted that the beginning of the training activity begins a sensitive period for the young student, laying the foundation for the future development of his personality. Starting a training activity involves individual, voluntary and intellectual preparation. Individual training involves focusing on the content of the learning activity in addition to the student's social status. Voluntary training is associated with the development of voluntariness and the ability to act in accordance with the rules set by the teacher. Intellectual training includes the development of the child's cognitive processes and mastery of the system of intellectual activity.

In our research with young schoolchildren, we can conclude that there are three symptoms of the 6-7 year old crisis, negative, neutral and positive, that arise when children start learning activities. Negative symptoms include disobedience to rules and regulations at home and at school, aggression, lying, refusal to go to school, loss of appetite and sleep; Neutral symptoms manifest themselves in behavioral features aimed at emphasizing the "growing up» of a junior schoolchild in connection with the development of the concept of «ego». All these features begin to disappear as the junior schoolchild emerges from the crisis and enters a new age. Positive symptoms are observed when the child overcomes the crisis situation and successfully adapts to the learning activity. As a result, the junior schoolchild's interests and social connections expand; Communication with adults and peers is becoming more independent. It should 
also be noted that positive symptoms do not appear suddenly in children. To do this, parents and teachers must help children cope with the crisis. First of all, the child must develop adequate self-esteem by building confidence in their abilities and skills. On the other hand, training materials should be appropriate for the age and individual characteristics of the children. It should be taken into account that the child is just getting acquainted with systematic learning.

Thus, based on the research, we can obtain the following relevant results:

- The main reason for the new 6-7-year-old crisis experienced by the child during the transition from preschool to school age is the exhaustion of his/her game development opportunities, the inability of images and roles, as well as toys to fully understand the world around him;

- The desire to go to school is not always associated with the desire and ability to learn. Thus, learning activities not only mean the beginning of a new activity for the child, but also the entry into the world of adults;

- Successful adaptation of a junior schoolchild to learning activities is an important condition for overcoming the crisis of 6-7 years. To do this, the child must not only understand what and why he/she is learning, but also be interested in learning - this is an important step for successful learning.

Since the child's main need at this age is the desire to be «big», it is necessary to develop independence in the child's actions, to entrust the issues he can cope with, to help determine his status in the family and in the classroom. However, it should be borne in mind that the child is not yet large and often forgets the tasks or can not control their emotions independently. In order to cope with these problems, it is necessary to create conditions for the child to control his actions on his own without the instructions of adults. As a result, the child gradually loses the characteristics of preschool age, and begins to pay attention to the meaning of movement and behavior, its social evaluation. In short, by becoming a «schoolboy» he becomes a subject of learning activities. A child who is a subject of learning activities can determine for himself what he will learn and how he will learn.

\section{REFERENCES / СПИСОК ВИКОРИСТАНИХ ДЖЕРЕЛ / СПИСОК ЛИТЕРАТУРЫ (TRANSLATED AND TRANSLITERATED)}

[1] L. Ş. Omrahlı, M. L. Oliyeva, Təlim faaliyyati və psixi inkişaf. Bakı, Azərbaycan, 2014. $173 \mathrm{~s}$.

[2] А. А. Рогова, «Развитие эмоциональной сферы младших школьников с нарушением интеллекта на уроках чтения», выпускная квалификационная работа. Екатеринбург, Россия, 2017, 60 с. 
[3] А. Э. Вейц, «Психологические особенности детей младшего школьного возраста с неврозоподобными расстройствами», дис. канд. наук. Санкт-Петербург, 2014, 163 с.

[4] Т. С. Колосова, Н.В.Звягина, Л.В.Морозова, Психофизиологические особенности развития детей младшего школьного возраста. Архангельск, Россия, 1997, 159 с.

[5] Е.А. Сергиенко, Т. Д. Марцинковская, Е. И. Изотова, Е. И. Лебедева, А. Ю. Уланова, Е. М. Дубовская, Социально-эмоциональное развитие детей. Теоретические основы. Москва, Россия, 2019, 248 с.

\title{
ПОЧАТОК НАВЧАЛЬНОЇ ДІЯЛЬНОСТІ МОЛОДШИХ ШКОЛЯРІВ. ВІКОВА КРИЗА ДІТЕЙ 6-7 РОКІВ
}

\author{
Айгун Рустамова, \\ співробітник Нахічеванського державного університету, \\ докторант Нахічеванського державного університету. \\ Нахічевань, Азербайджан. \\ ORCID iD: https://orcid.org/0000-0003-2682-9485 \\ res0980@mail.ru
}

Анотація. У статті обговорюються питання початку навчальної діяльності молодших школярів та вікової кризи 6-7 років. Початок навчальної діяльності для дітей віком 6-7 років є однією 3 найважливіших проблем початкової освіти 3 погляду адаптації до шкільного середовища. У цей період відбувається також багато змін, пов'язаних із психофізіологічним розвитком дитини. Отже, дитина поєднує риси дошкільного віку з особливостями шкільного віку. Цей віковий період $є$ актуальним і сьогодні, незважаючи на те, що його достатньо вивчено і відображено, зокрема в психологічній та педагогічній літературі. У статті також порушуються проблеми психологічних особливостей молодших школярів. Слід зазначити, що діти, які вступають до першого класу, переходять до нового стану соціального розвитку, оскільки гра замінюється навчальною діяльністю, у якій вони отримують не лише нові права й обов'язки, а й обов'язки, які мають відповідати вимогам школи. Виходячи 3 результатів дослідження, можна стверджувати, що для того, щоб діти 6-7 років легко адаптувалися до навчальної діяльності, слід підготувати їх до певного навчання, викликати інтерес до школи. 3 іншого боку, успіх адаптації молодших школярів до навчання буде досягнуто, якщо враховувати їхні когнітивні й емоційні 
характеристики. $\mathrm{y}$ процесі дослідження було використано результати спостережень, опитувань та експериментів, проведених у загальноосвітній школі імені Х. Алієва у Нахічевані у 2018-2019 роках, а також матеріали, зазначені у бібліографії.

Ключові слова: молодші школярі; навчальна діяльність; адаптація; криза віку 6-7 років; предмет; психічні процеси; фізичний розвиток; емоційність; дошкільний стан; поведінка.

\title{
НАЧАЛО УЧЕБНОЙ ДЕЯТЕЛЬНОСТИ МЛАДШИХ ШКОЛЬНИКОВ. ВОЗРАСТНОЙ КРИЗИС ДЕТЕЙ 6-7 ЛЕТ
}

\author{
Айгюн Рустамова, \\ сотрудник Нахичеванского государственного университета, \\ докторант Нахичеванского государственного университета. \\ Нахичеван, Азербайджан. \\ ORCID iD: https://orcid.org/0000-0003-2682-9485 \\ res0980@mail.ru
}

Аннотация. В статье обсуждаются вопрос начала учебной деятельности младших школьников и возрастной кризис детей 6-7 лет. Начало учебной деятельности для детей 6-7 лет - одна из важнейших проблем начального образования с точки зрения адаптации к школьной среде. В этот период происходит много изменений в связи с психофизиологическим развитием ребенка. Итак, ребенок сочетает черты дошкольного возраста с особенностями школьного возраста. Этот возрастной период является актуальным и сегодня, несмотря на то, что он достаточно изучен и отображен, в частности в психологической и педагогической литературе. В статье также поднимаются проблемы психологических особенностей младших школьников. Следует отметить, что дети, которые вступают в первый класс, переходят в новое состояние социального развития, поскольку игра заменяется учебной деятельностью, в которой они приобретают не только новые права и обязанности, но и обязанности, которые должны соответствовать требованиям школы. По результатам исследования можно сказать, что для того, чтобы дети в возрасте 6-7 лет легко адаптировались к учебной деятельности, необходимо подготовить их к определенному обучению, вызвать интерес к школе. С другой стороны, успех в адаптации младших школьников к обучению будет достигнут, если учитывать их когнитивные и эмоциональные 
характеристики. В процессе исследования были использованы результаты наблюдений, опросов и экспериментов, проведенных в общеобразовательной школе имени Х. Алиева в Нахичеване в 20182019 годах, а также материалы, указанные в библиографии.

Ключевые слова: младшие школьники; учебная деятельность; адаптация; кризис 6-7 лет; предмет; психические процессы; физическое развитие; эмоциональность; дошкольное состояние; поведение.

\section{REFERENCES (TRANSLATED AND TRANSLITERATED)}

[1] L. S. Amrahli, M. L. Alieva, Trenirovochnaya deyatel'nost' i umstvennoe razvitie. Baku, Azerbajdzhan, 2014. 173 s.

[2] A. A. Rogova, «Razvitie emocional'noj sfery mladshih shkol'nikov s narusheniem intellekta na urokah chteniya», vypusknaya kvalifikacionnaya rabota. Ekaterinburg, Rossiya, 2017, $60 \mathrm{~s}$.

[3] A. E. Vejc, «Psihologicheskie osobennosti detej mladshego shkol'nogo vozrasta s nevrozopodobnymi rasstrojstvami», dis. kand. nauk. SanktPeterburg, 2014, 163 s.

[4] T. S. Kolosova, N. V. Zvyagina, L. V. Morozova, Psihofiziologicheskie osobennosti razvitiya detej mladshego shkol'nogo vozrasta. Arhangel'sk, Rossiya, 1997, 159 s.

[5] E. A. Sergienko, T. D. Marcinkovskaya, E. I. Izotova, E. I. Lebedeva, A. YU. Ulanova, E. M. Dubovskaya, Social'no-emocional'noe razvitie detej. Teoreticheskie osnovy. Moskva, Rossiya, 2019, 248 s. 